\title{
Identification of Phytoconstituents in Lawsonia inermis Linn. Leaves Extract by GC-MS and their Antibacterial Potential
}

\author{
Ritesh Kumar Sharma ${ }^{1,{ }^{*}}$, Anjana Goel ${ }^{2}$
}

\section{Ritesh Kumar Sharma ${ }^{1, *}$, Anjana Goel ${ }^{2}$}

'Ph.D.Scholar, Department of Biotechnology, IAH, GLA University, Mathura, Uttar Pradesh, INDIA. ${ }^{2}$ Associate Professor, Department of Biotechnology, IAH, GLA University, Mathura, Uttar Pradesh, INDIA.

\section{Correspondence}

\section{Dr. Ritesh Kumar Sharma}

\section{Ph.D. Scholar, Department of} Biotechnology, IAH, GLA University, $17 \mathrm{~km}$ stone, NH2, Mathura-Delhi road, PO Chaumuhan, Mathura- 281406, Uttar Pradesh, INDIA.

Phone no : +919897006326

E-mail: sharmaanshul603@gmail.com

\section{History}

- Submission Date: 14-03-2018;

- Review completed: 28-06-2018;

- Accepted Date: 11-07-2018

\section{DOI : 10.5530/pj.2018.6.187}

Article Available online

http://www.phcogj.com/v10/i6

\section{Copyright}

(C) 2018 Phcog.Net. This is an openaccess article distributed under the terms of the Creative Commons Attribution 4.0 International license.

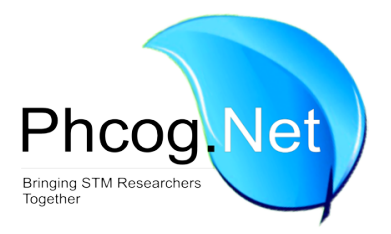

\begin{abstract}
Background: Plant extracts contains multiple active constituents which leads to the production of new drugs from plants and chemicals derived from various parts of plants. The objective of present study was to investigate the GC-MS analysis and antibacterial activity of L. inermis leaves extracts. Material and Methods: Crude methanol extract and its fractions were tested for the presence of active phytochemicals and GC-MS analysis of hexane; ethyl acetate and aqueous methanol fractions was performed. Antimicrobial activity against six bacterial strain's Escherichia coli, Staphylococcus aureus, Bacillus subtelis, Salmonella typhi, Klebsiella and Pseudomonas aeruginosa was also tested. Results: Phytochemical screening of extract confirmed the presence of carbohydrates, glycosides, quinones, steroids and phenol. In GC-MS chromatograms, 56, 108 and 19 peaks were obtained and out of these, 13, 17 and 7 compounds were identified in hexane, ethyl acetate and aqueous methanol fractions, respectively. Conclusion: For best of our knowledge in L. inermis leaves extract, Celidoniol and Vitamin E has not been reported earlier in hexane fractions. While 2, 3 dihydrobenzo furan, 1-H indole -1, 3 (2H)-dione, 1 (3H)-Isobenzofuranone, 1H Isoindole-1, 3 (2H) Dione, Napthelene, 2 ethoxy, 2 (4H) Benzofuranone, Vitamin E, Benzene, 1 isocyano 4 methyl are also identified for the first time in ethyl acetate fraction. Also, in aq. Methanol fraction 1(3H)-isobenzofuranone, Squalene and Vit E were not previously identified. Highest antibacterial activity was confirmed in crude methanol extract which might be due to all the antibacterial compounds present in its fractions. The present study helped in identifying phytoconstituents present in the extract and its fractions which are responsible for various biological and antibacterial activities.
\end{abstract}

Key words: Lawsonia inermis Linn., Methanol extract, Lawsone, 1,4 Napthelenedione, Antimicrobial activity, Medicinal plants.

\section{INTRODUCTION}

Since the beginning of human civilization plants are used by mankind for their therapeutic values. ${ }^{1}$ The books on the ayurvedic medicine such as 'Susruta samhita' and 'Charak samhita' refer to the use more than 700 herbs, which are now becoming an important part of daily life despite the progress in modern medicinal and pharmaceutical research. ${ }^{2-3}$ Plant extracts contains multiple active constituents, unlike modern medicine that invariables comprise single active ingredients, presenting herbal cocktail showing synergistic and less side effect. It leads to the production of new drugs from plants and chemicals derived from various parts of plants. ${ }^{4-5} \mathrm{~A}$ wide variety of secondary metabolites such as tannins, terpenoids, alkaloids and flavanoids are present in plants, which show antimicrobial properties, ${ }^{6-10}$ resulting their use as ethno medicine in different countries around the world. ${ }^{11-13}$

Indian continent is blessed with 120 families and 130000 species of plants. Many of these are known to have medicinal properties. From historical time, various parts of these plants have been used in treatment of communicable as well as non-communicable diseases. However, the bioactive phytoconstituents contributing to antimicrobial properties are yet to be discovered. ${ }^{14}$ As from the above, it can be easily understood that some medicinally and pharmacologically important active ingredients play an important role in the biological activities like antibacterial activity of plants. Herbals are a rich source of active ingredients and can be safer and cost effective treatment for skin diseases ranging from rashes to dreadful skin cancer. ${ }^{15}$ To well document their role, several researchers are investigating the biological activities of several plants, which are leading to the development of many synthetic antibiotics. ${ }^{16}$

Genus Lawsonia have only one sps. Lawsonia inermis Linn. common name Henna/Mehndi. ${ }^{17-18}$ Prominent areas for the growth of $L$. inermis Linn. are tropical regions of Asia, America and Africa. ${ }^{8-19}$ This plant is mignonette tree ${ }^{20}$ belong to Kingdom- Plantae, Division- Angiosperm, Class- Dicotyledon, OrderMyrtales, Family- Lythraceae, Genus- Lawsonia, 
Species- L. inermis. ${ }^{21-22}$ Microscopic evaluation of L. inermis powders showed the fragment of mesophyll, fragment of parenchyma, epidermis layer with stomata, and the rosette crystal of calcium oxalate. ${ }^{23}$ There is no much information about the physicochemical proprieties of henna's aromatic oil, plant parts gives yellowish liquid aromatic oil, from seed and leaves, brown or dark brown color and strong fragrance from the flowers, with $0.01-0.02 \%$ of yield from flowers. ${ }^{24}$

Earlier, this plant was used as hair dye and in cosmetics. ${ }^{25}$ But now days, it is used as a medicinal plant. ${ }^{8,26}$ The leaves of this plant showed antiinflammatory, antipyretic, analgesic, antifungal and antibacterial activity. ${ }^{27-31}$ Lawsone (2-hydroxy napthaquinone), mucilage, mannite, gallic acid and tannic acid were found to be the main chemical constituents which might be having a role in its medicinal properties. ${ }^{32}$

Previous studies have shown that L. inermis. Linn. exhibits antibacterial effect only against gram positive bacteria ${ }^{33}$ but later antibacterial effect was also observed against gram negative bacteria. ${ }^{34}$ Considering this, an attempt has been made to investigate the phytochemical screening and antibacterial activity of crude methanol extract and different solvent fractions of L. inermis Linn. leaves.

\section{MATERIALS AND METHODS}

\section{Collection of plant material and authentication}

L. inermis Linn. plant leaves were collected from G.L.A. University campus, Mathura and were authenticated by Dr. (Mrs.) A. S. Upadhye (Voucher no. L-081), Botany group, Plant Science Division, Agharkar Research Institute, Pune. Leaves were washed thoroughly with tap water then rinsed with distilled water three times. After it leaves were shade dried, coarsely powered and packed in airtight bottle for the preparation of extract.

\section{Preparation and Fractionation of crude methanol extract}

Method as described by Muhit et al. ${ }^{35}$ was used with slight modifications for the preparation and fractionation of crude methanol extract of L. inermis leaves. In brief, $15 \mathrm{~g}$ of leaves dry powder was soaked in $250 \mathrm{~mL}$ of methanol for one week with occasional shaking. At the end of the week, the extract was filtered using a Whatmans No.1 filter paper and crude methanol extract was evaporated to dryness at $40^{\circ} \mathrm{C}$ in oven. This extract was fractionated by using solvents of increasing polarity. Extract in $90 \%$ methanol was taken in to a separating funnel, and equal volume of hexane was mixed to it. Upper hexane layer was separated from lower methanol layer. Now, upper hexane layer was dried in oven at $40^{\circ} \mathrm{C}$ and methanol layer was further separated into ethyl acetate and aqueous methanol layer by adding equal volume of ethyl acetate and distilled water. Both the layers were dried in hot air oven at $40^{\circ} \mathrm{C}$.

\section{Preliminary phytochemical screening of plant leaves extract and its fractions}

Crude methanol extract and its fractions were tested for the presence of active phytochemicals such as alkaloids, carbohydrates, saponins glycoside, flavanoids, triterpenoids and proteins by standard procedures as described by Debela. ${ }^{36}$ Mayer's test, Hager's test and Dragendorff's test were performed for alkaloids, Legal's test for identifying glycosides while ferric chloride test to determine the presence of tannins and polyphenolic compounds. Ninhydrin and Biuret test were used to detect proteins and flavonoids were tested through alkaline tests. Furthermore, steroids were identified through Salkowaski test and the presence of carbohydrates was done through Biuret and fehling's test.

\section{Gas Chromatography-Mass Spectrometry (GC-MS)}

Analysis

The GC-MS was performed by using Agilent 7683 series model and the software used is Chem. Station software updated with Mass productivity software. The fused silica column was packed with HP-5MS (5\% Phenylmethylsulphoxane) of $30 \mathrm{~m} \times 250 \mu \mathrm{m} \times 0.25 \mu \mathrm{m}$ dimensions. The oven temperature was started from $50^{\circ} \mathrm{C}$ with an increase of $3^{\circ} \mathrm{C} / \mathrm{min}$ up to $240^{\circ} \mathrm{C}$ with holding time of $5 \mathrm{~min}$. Temperature further enhanced gradually at $15^{\circ} \mathrm{C} / \mathrm{min}$ up to $270^{\circ} \mathrm{C}$ with holding time of $40 \mathrm{~min}$. Helium gas (99.999\%) was used as the carrier gas at constant flow rate of $1 \mathrm{ml} / \mathrm{min}$. An aliquot of $1 \mu \mathrm{l}$ of sample was injected into the column at injector temperature $270^{\circ} \mathrm{C}$ with split ratio of 20:80. The ionizing energy of $70 \mathrm{eV}$ was used for electron ionization of molecules. The mass range is 30-550amu. Total GC running time was $90 \mathrm{~min}$. The identification was done with the help of Wiley 2010 library.

\section{Bioassay studies \\ Test microorganisms}

Antimicrobial activity against six bacterial strain's Escherichia coli (MTCC No. 40), Staphylococcus aureus, Bacillus subtelis (MTCC No. 10619), Salmonella typhi (MTCC No. 3231), Klebsiella and Pseudomonas aeruginosa (MTCC No. 424) was tested. All the strains were biochemically tested, identified and authenticated.

\section{Determination of bacterial cell count}

Each strain of bacteria was inoculated in nutrient broth for $24 \mathrm{~h}$. After incubation of $24 \mathrm{~h}$, nutrient broth was removed by centrifugation and bacterial pellet was reconstituted in normal saline. Bacterial cell count was estimated by matching the turbidity of bacterial cell suspension with McFarland nephlometer. ${ }^{37}$

\section{Antibacterial assay}

Antibacterial activity against six bacterial strains was determined by disc diffusion method as described by Parekh et al. ${ }^{39} 5,10$ and $20 \mathrm{mg} / \mathrm{disc}$ of extract and its fractions were loaded on filter discs and were screened against six bacterial strains on nutrient agar plates. One negative control disc was also placed to nullify the effect of solvent on bacterial growth. Each bacterial strain was also screened for standard antibiotic disc which acted as positive control. After incubation of $24 \mathrm{~h}$ at $37^{\circ} \mathrm{C}$, the plates were observed for the presence of zones of inhibition as evidence of antibacterial activity. The degree of sensitivity was determined by measuring the diameter of visible zones of inhibition to the nearest millimetres with respect to each bacterial strain and extract concentration.

\section{RESULTS}

\section{Extract preparation (percentage yield)}

The physical characteristics of crude methanol extract of the Lawsonia inermis leaves and its different solvent fractions are shown in Table 1. The methanol extract was dark green in colour, oily in texture and percentage yield was $17 \%$. Aqueous methanol fraction has $11.70 \%$ percentage yield which is higher as compare to hexane $(0.66 \%)$ and ethyl acetate fraction $(0.96 \%)$, indicating higher percentage of polar compound as compared to nonpolar.

The percentage recovery of the individual fraction was 4.0, 5.7 and $70.0 \%$ respectively. Approximately $20 \%$ of extract was lost during extraction and drying procedure. Hexane and aqueous methanol extract were oily whereas ethyl acetate extract was dry powder in texture. Hexane, ethyl acetate and aqueous methanol were greenish, brownish and reddish in colour respectively, the variation in colour was due to the difference in the solubility of different chemical constituents. 


\section{Preliminary Phytochemical screening of plant leaves} extract and its fractions

The presence of different phytochemical constituents in the crude methanol extract and its fractions are shown in Table 2. Carbohydrates along with glycosides, quinones, steroids, phenol were present in the extract and its fractions while proteins were absent.

\section{Gas Chromatography-Mass Spectrometry (GC-MS) Analysis \\ GC-MS of Hexane fraction}

The GC-MS chromatograms (Figure 1a, 1b and 1c) of the hexane fraction clearly showed peaks indicating the presence of phytochemical compounds

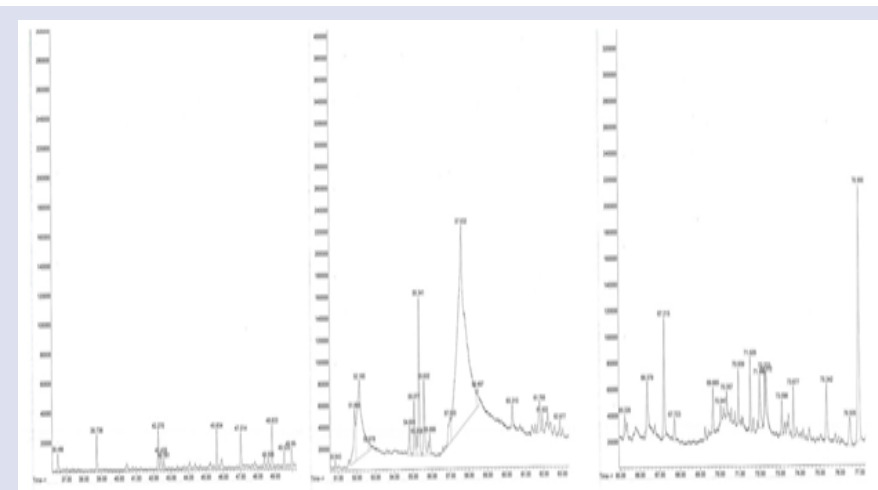

Figure 1: GC-MS Chromatograms of Hexane fraction of $L$. inermis leaves.

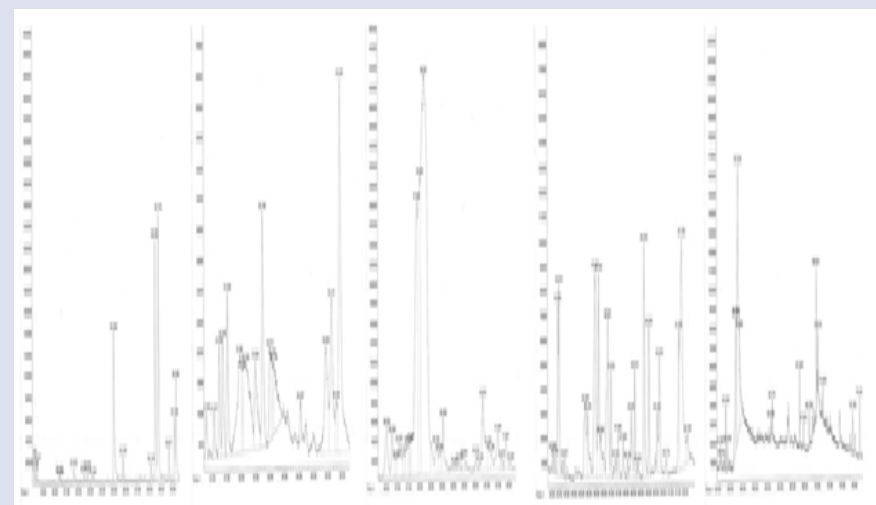

Figure 2: GC-MS Chromatograms of Ethyl acetate fraction of $L$.inermis leaves and the chemical compounds identified are shown in Table 3. In GC-MS chromatogram 56 peaks were present. Out of these 13 peaks were identified and their biological properties were referenced from available literature (Table 3 ). In addition to these compounds, approximately 20 peaks were also obtained in the chromatogram. These peaks refer different compounds present in large quantities, like peak RT - 57.632 having area - 41.63, RT -52.165 area 9.47 but they were not identified by the library.

\section{GC-MS of Ethyl acetate fraction}

The GC-MS chromatograms of the ethyl acetate fraction clearly showed 108 peaks (Figure 2a, 2b, 2c, 2d and 2e) indicating the presence of large no. of phytochemical compounds. Their biological activities are indicated

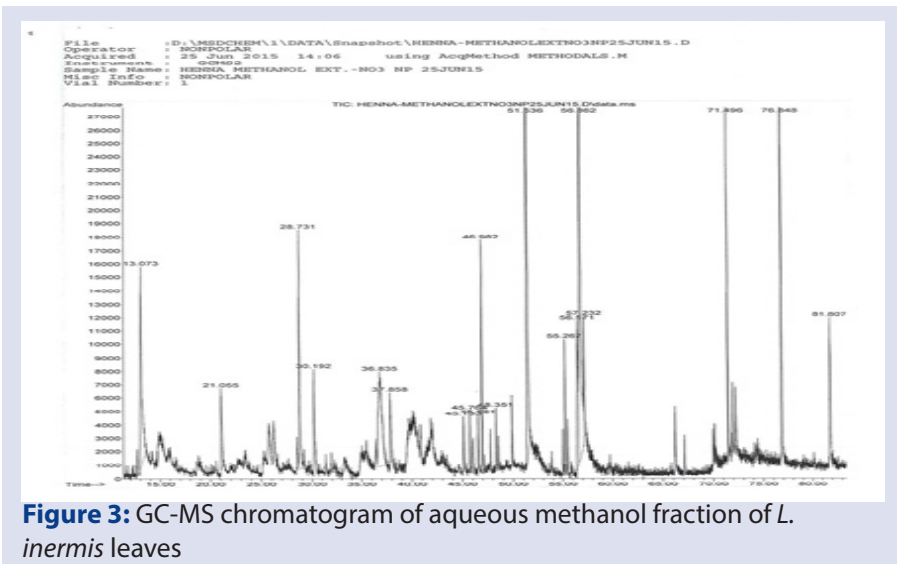

Table 1: Percentage yield of Lawsonia inermis Linn. plant leaves extract.

\begin{tabular}{cccccc}
\hline S.No. & $\begin{array}{c}\text { Extract/ } \\
\text { fraction of } \\
\text { extract }\end{array}$ & Color & Texture & $\begin{array}{c}\text { Percentage } \\
\text { yield }\end{array}$ & $\begin{array}{c}\text { Recovery } \\
\text { yield }\end{array}$ \\
\hline 1. & $\begin{array}{c}\text { Crude } \\
\text { Methanol }\end{array}$ & Brownish & Oily & $17 \%$ & \\
2. & Hexane & Greenish & Oily & $0.66 \%$ & $4 \%$ \\
$3 . \quad$ & $\begin{array}{c}\text { Ethyl Acetate } \\
\text { Aqueous }\end{array}$ & Brownish & Dried & $0.96 \%$ & $5.7 \%$ \\
$4 . \quad \begin{array}{c}\text { methanol } \\
\text { extract }\end{array}$ & Reddish & Oily & $11.7 \%$ & $70 \%$ \\
\hline
\end{tabular}

Table 2: Qualitative analyses of Phytochemicals present in crude methanol extract and their different fractions of Lawsonia inermis Linn. plant leaves

\begin{tabular}{cccccc}
\hline $\begin{array}{c}\text { S. } \\
\text { No. }\end{array}$ & Test used & $\begin{array}{c}\text { (Crude methanol } \\
\text { extract) }\end{array}$ & (Hexane fraction) & (Ethyl acetate fraction) & $\begin{array}{c}\text { (Aqueous Methanol } \\
\text { Fraction) }\end{array}$ \\
\hline 1. & Alkaloids & $+\mathrm{ve}$ & $+\mathrm{ve}$ & $+\mathrm{ve}$ & $+\mathrm{ve}$ \\
$\mathbf{2}$ & $\begin{array}{c}\text { Glycosides } \\
\text { compounds }\end{array}$ & $+\mathrm{ve}$ & $+\mathrm{ve}$ & $+\mathrm{ve}$ & $+\mathrm{ve}$ \\
3. & Flavonoids & $-\mathrm{ve}$ & $+\mathrm{ve}$ & $+\mathrm{ve}$ & $+\mathrm{ve}$ \\
$\mathbf{4 .}$ & Proteins & $-\mathrm{ve}$ & $-\mathrm{ve}$ & $-\mathrm{ve}$ & $-\mathrm{ve}$ \\
$\mathbf{5 .}$ & Carbohydrates & $+\mathrm{ve}$ & $+\mathrm{ve}$ & $+\mathrm{ve}$ & $+\mathrm{ve}$ \\
$\mathbf{6 .}$ & Steroids & $+\mathrm{ve}$ & $+\mathrm{ve}$ & $+\mathrm{ve}$ & $+\mathrm{ve}$ \\
7. & Phenol & $+\mathrm{ve}$ & $+\mathrm{ve}$ & $+\mathrm{ve}$ & $+\mathrm{ve}$ \\
$\mathbf{8 .}$ & Quinones & $+\mathrm{ve}$ & $+\mathrm{ve}$ & $+\mathrm{ve}$ & $+\mathrm{ve}$ \\
\hline
\end{tabular}

Key: -+ ve $=$ present, - ve $=$ absent 
Table 3: Chemical compounds identified in GC-MS of Hexane fraction with their biological properties

\begin{tabular}{ccccc}
\hline S.No. & R.T. & Area & Compound Name & Biological activity \\
\hline 1. & 36.486 & 0.39 & Phenol & Antiseptic, Topical anaesthetic ${ }^{39}$ \\
2. & 42.270 & 0.78 & Eicosane & Antitumor activity against human gastric SGC-7901 cell line ${ }^{40}$ \\
3. & 45.634 & 0.67 & Nonadecane & No medicinal activity is known so far \\
4. & 48.833 & 0.76 & Celidoniol & Anti inflammatory, antioxidant, wound healing activity \\
5. & 52.165 & 9.47 & Hexadecanoic acid & Antimicrobial activity \\
6. & 55.077 & 1.43 & Ethyl-9,12 octadecadienoate & Nematicide, Hepatoprotective, Anticoronary ${ }^{43}$ \\
7. & 55.208 & 0.53 & 9 -octadecanoic acid & Antioxidant, anti-inflammatory \\
8. & 55.341 & 4.14 & $9,12,15$-octadecatrienoic acid & Antioxidant, anti-inflammatory \\
9. & 67.215 & 2.67 & 1,2 Benzenedicarboxylic acid & Antimicrobial activity \\
\hline
\end{tabular}

Table 4: Phytochemical compound identified in GC-MS of Ethyl acetate fraction of leaves of $L$. inermis and their biological activities

\begin{tabular}{|c|c|c|c|c|}
\hline S. No. & R.T. & Area & Compound Name & Biological activity \\
\hline 1. & 18.33 & 0.20 & Benzoic acid, methyl ester & No activity reported \\
\hline 2. & 25.00 & 2.51 & 2,3 dihydrobenzo furan & Anti-inflammatory ${ }^{50}$ \\
\hline 3. & 28.49 & 3.33 & 2-methoxy 4 vinyl phenol & Flavour and Perfumery $y^{39,43}$ \\
\hline 4. & 28.78 & 3.97 & Pthalic anhydride & Anticonvulsant activity ${ }^{51}$ \\
\hline 5. & 29.67 & 0.44 & 1- $\mathrm{H}$ indole $-1,3(2 \mathrm{H})$-dione & Antimicrobial and anticoagulant ${ }^{52}$ \\
\hline 6. & 30.15 & 0.71 & $1(3 \mathrm{H})$-Isobenzofuranone & Antimicrobial, antifungal and anti-inflammatory ${ }^{53}$ \\
\hline 7. & $37.83-41.06$ & 36.54 & 1,4 Napthalenedione & $\begin{array}{l}\text { Antimicrobial, antifungal, antiviral, insecticidal, anti-inflammatory, } \\
\text { antipyretic }\end{array}$ \\
\hline 8. & $33.02-33.14$ & 0.64 & 1,2,3-Benzenetriol & Antioxidant, antiseptic, antibacterial, antidermatic, fungicide, pesticide ${ }^{39,43}$ \\
\hline 9. & 34.05 & 0.07 & Phenol,2 methoxy-4 (2 Propenyl) & Antiseptic, topical anesthetic ${ }^{39}$ \\
\hline 10. & 35.14 & 0.49 & 1H Isoindole-1, 3 (2H) Dione & Antibacterial, analgesic, anti-inflammatory, antipyretic ${ }^{55}$ \\
\hline 11. & 36.77 & 0.86 & Napthelene, 2 ethoxy & Antibacterial and antifungal ${ }^{56}$ \\
\hline 12. & 46.19 & 1.28 & $2(4 \mathrm{H})$ Benzofuranone & Antimicrobial, antifungal and anti-inflammatory ${ }^{53}$ \\
\hline 13. & 48.62 & 0.53 & 1,2 Benzene dicarboxylic acid & Antimicrobial activity ${ }^{42}$ \\
\hline 14. & 51.79 & 2.79 & Hexadecanoic acid & Antioxidant ${ }^{57,47}$ \\
\hline 15. & 55.31 & 0.39 & $9,12,15$ octadecatrienoic acid & Antioxidant and anti-inflammatory ${ }^{58}$ \\
\hline 16. & 76.90 & 0.44 & Vitamin E & Antioxidant ${ }^{49}$ \\
\hline 17. & 28.13 & 0.125 & Benzene, 1 isocyano 4 methyl & Antibacterial and antifungal ${ }^{59}$ \\
\hline
\end{tabular}

in Table 4. 1, 4 Napthelenedione 2 hydroxy compound was present in highest concentration $(36.54 \%)$.

\section{GC-MS of Aqueous methanol fraction}

In GC-MS (Figure 3) of aqueous methanol fraction, 19 peaks were obtained and out of which 7 compounds were identified. 9, 12-octadecadienoic acid ethyl ester was found in highest concentration. $1(3 \mathrm{H})$ isobenzofuranone, Squalene and Vit $\mathrm{E}$ were also identified in this fraction. Biological activities of identified phytochemical are shown in Table 5.

\section{Bioassay studies}

Table 6 showed antibacterial activity of methanol extract and their fractions at different concentrations against different bacterial strains.
The antibacterial activity was illustrated in terms of zone of inhibition $(\mathrm{mm})$ formed against bacterial strains. Results are illustrated in Table 6. Hexane fraction showed least antibacterial response whereas ethyl acetate and aq. methanol fraction confirm more or less equal response against all bacterial strains. Extract and their fractions confirmed the effective response in dose dependent manner. Against all bacterial strain, positive control had highest antibacterial property as compared with extract and its fractions.

\section{DISCUSSION}

L. inermis is used in various cosmetic things such as dye from the earlier times but this plant also has good medicinal value due to the presence 
Table 5: Biological activities of phytochemical compounds identified in GC-MS of aqueous methanol fraction of Leaves of Lawsonia inermis

\begin{tabular}{ccccc}
\hline S. No. & Chemical compound & R.T. & Area & Biological Activity \\
\hline 1. & 4H-Pyran-4-one & 21.05 & 2.07 & Antimicrobial, ant proliferative and anti-inflammatory $^{60}$ \\
2. & 1,3 -isobenzofurandione & 28.73 & 6.11 & Antimicrobial, antifungal and anti-inflammatory $^{53}$ \\
3. & $1(3 \mathrm{H})$-isobenzofuranone & 30.19 & 3.16 & Antimicrobial, antifungal and anti-inflammatory $^{53}$ \\
4. & n-Hexadecanoic acid & 51.53 & 15.03 & Antioxidant and Antimicrobial activity ${ }^{42,47,57}$ \\
5. & 9,12 -octadecadienoic acid ethyl & 56.86 & 19.25 & Nematicide, Hepatoprotective, Anticoronary \\
& ester & & & Antioxidant, antitumor \& immunostimulant \\
6. & Squalene & 71.49 & 3.71 & Antioxidant activity $^{49}$ \\
7. & Vit. E & 76.85 & 10.55 &
\end{tabular}

of various phytochemicals which are responsible for various biological activities. ${ }^{24}$ The present study was conducted to identify the phytochemical constituents responsible for their biological role and antibacterial activity in L. inermis leaves.

As shown in Table 1, the percentage yield of methanol extract of L. inermis was $17 \%$ while recovery yield of Hexane, ethyl acetate and methanol fractions were $4 \%, 5.7 \%$ and $70 \%$, respectively. It indicates that approximately $20 \%$ was lost during the fractionation. Kawo and Kwa ${ }^{61}$ reported $1.8 \%$ ethyl acetate fraction yield which is lower than our report while recovery yield of aq. methanol fraction is higher (87.19\%) than our reported value.

The result of phytochemical study confirmed the presence of various primary and secondary metabolites such as flavanoids, carbohydrates, quinones, steroids and phenols. Presence of these phytochemicals in L. inermis leaves extracts are responsible for various biological activities such as antibacterial, antioxidant, anti-inflammatory activities, etc. ${ }^{62}$ Most of the phytochemicals are present in extract and its fraction as shown in our study. Whereas protein was found to be absent in extract as well as in its fractions.

GC-MS analysis of different fractions of $L$. inermis revealed the presence of different phytochemical compounds. These phytochemical compounds have medicinal property as reported earlier. GC-MS analysis of hexane fraction showed 56 peaks based on retention time. Out of these, 13 phytochemical constituents were identified by GC-MS software library and most of them showed biological activity as evidences by literature (Table 3). For best of our knowledge, Celidoniol and Vitamin E has not been reported earlier in L. inermis leaves fractions. In the hexane extract, 5 chemical compounds were present in high concentration, out of which 2 were identified viz. Hexadecanoic acid (9.47\%), Vit. E (7.41\%) while 3 peaks which were not identified having $\%$ area i.e. $1.43 \%, 1.22 \%$ and $1.01 \%$ with RT- 55.07, 75.342 and 76.506 respectively.

In GC-MS of ethyl acetate fraction 108 peaks were observed and 17 phytochemical compounds were identified. Out of which 1, 4 Napthalenedione was identified as major constituent. Dama et al. ${ }^{63}$ also reported this compound which is responsible for the antibacterial effect. This compound also has been reported in other literature and have antimicrobial, antifungal, antiviral, insecticidal, anti-inflammatory and antipyretic activities. ${ }^{39,64}$ Biological activities of other compounds are shown in Table 4. Benzoic acid, methyl ester was also identified in chromatogram, but no biological activity has been reported so far. Some phytoconstituents such as 2,3 dihydrobenzo furan, $1-\mathrm{H}$ indole $-1,3(2 \mathrm{H})$-dione, $1(3 \mathrm{H})$ Isobenzofuranone, $1 \mathrm{H}$ Isoindole-1, 3 (2H) Dione, Napthelene, 2 ethoxy, $2(4 \mathrm{H})$ Benzofuranone, Vitamin E, Benzene, 1 isocyano 4 methyl were also identified in this fraction for the first time and are not mentioned in earlier references. Ethyl acetate fraction had 5 peaks present in higher concentration. Out of these 4 peaks 1,4 Napthalenedione, 2 hydroxy
(36.54\%), 2-methoxy 4 vinyl phenol (3.33\%), Pthalic anhydride (3.97\%), Hexadecanoic acid $(2.79 \%)$ were identified and single peak present at RT- 57.31 was not identified having area $6.68 \%$.

GC-MS analysis of aq. methanol fraction had 19 peaks and 7 compounds were identified. In this fraction 3 new compounds $1(3 \mathrm{H})$-isobenzofuranone, Squalene and Vit E were identified, and these compounds have biological properties. Methanol fraction had 5 major peaks based on $\%$ peak area viz $\{(9.44 \%$ and RT- 36.84$),(8.53 \%$ and RT- 13.07$),(5.06 \%$ and RT- 56.57), (3.25\% and RT- 57.23) and (3.19\% and RT- 46.98$)\}$ and all these major peaks were not identified.

Some common compounds such as Vitamin E and Hexadecanoic acid which were present in all fractions and has antioxidant activities. ${ }^{47,49,57}$ Phenol, 1, 2 Benzene carboxylic acid and 9,12,15 occtadeactrienoic acid were present in hexane and ethyl acetate fractions and were absent in aq. methanol fraction. Furthermore, in aq. methanol and hexane fractions, Squalene and 9, 12-octadecadienoic acid ethyl ester were common but were not identified in ethyl acetate fraction. Common phytochemical compounds in methanol and ethyl acetate fractions were Pthalic anhydride and $1(3 \mathrm{H})$-Isobenzofuranone.

As per Panchaksharam et al. ${ }^{62}$ L. inermis shows higher total phenolic content and possess a single peak for simple phenols as obtained from chromatog. Moreover, it exhibits maximum zone of inhibition on both $g$ positive and $g$ negative organisms. Since, the amount of phenolic compound was proportional to antimicrobial activity.

Different fractions of $L$. inermis were analyzed against 6 bacterial strains for antibacterial activity. These fractions showed antibacterial activity in dose dependent manner. Results are illustrated in Table 6. As shown in results, hexane fraction showed highest antibacterial activity against E. coli whereas moderate antibacterial activity was found against Bacillus subtelis and Klebsella. However, hexane fraction failed to show activity against Staphylococcus citrus, S. typhi and Pseudomonas. Hexane fraction showed least antimicrobial activity due to the presence of only 2-3 compounds responsible for antimicrobial activity such as Hexadecanoic acid. Sarojini et al. ${ }^{66}$ also reported antibacterial activity of hexane fraction against Staphylococcus, E. coli and Bacillus subtilis.

Ethyl acetate fraction illustrated better results than hexane fraction. This fraction confirmed good activity against Bacillus subtelis and E. coli while moderate antibacterial activity was confirmed against other strains. This antibacterial activity might be due to the presence of 1, 4 Napthalenedione which was present in very high conc. Some researcher like Sarojini et al. ${ }^{66}$ and Kawo and $\mathrm{Kwa}^{63}$ demonstrated better antibacterial activity of ethyl acetate fraction as compare to hexane fraction which is similar to our results.

Aq. Methanol fraction demonstrated maximum zone of inhibition against $S$. typhi whereas this fraction had moderate antibacterial activity against other bacteria. However, it failed to show effective response 
against Staphylococcus citrus. Antibacterial activity might be due to the presence of some phytoconstituents such as Hexadecanoic acid, 4H-Pyran-4-one, 1, 3-isobenzofurandione and 1(3H)-isobenzofuranone which are reported in our studies by GC-MS analysis.

Crude methanol extract showed highest antibacterial activity as compared to its fractions against most of the bacteria. It may be due to presence of all phytoconstituents which were present in its fractions. However, positive control was potent than all fractions.

Our study confirms the previous work on $L$. inermis leaves extracts and its fractions. According to our study, plant leaves extract and its fraction have various phytoconstituents exhibiting antimicrobial activity against gram +ve and gram -ve bacteria. It gives an idea that $L$. inermis contain various phytoconstituents which have effective antibacterial properties. In further studies in-vivo activity of this plant extract should be done, so that it can be used in human welfare as medicine for treating different diseases.

\section{CONCLUSION}

An attempt was made to identify the phytochemical constituents responsible for their biological role and antibacterial activity in Lawsonia inermis Linn. leaves extract. The result of phytochemical study confirmed the presence of various primary and secondary metabolites such as flavonoids, carbohydrates, quinones, steroids and phenols which are responsible for various biological activities. The present study also helped in identifying phytoconstituents present in the extract and its fractions which are responsible for various biological and antibacterial activities. Thus, the present study helped in identifying phytoconstituents present in the extract and its fractions which are responsible for various biological and antibacterial activities.

\section{ACKNOWLEDGEMENT}

The authors wish to thanks to Hon'ble Vice-Chancellor, GLA University, Mathura, UP, India for providing the funding and Director, IAH, Department of Biotechnology, GLA University, Mathura, UP, India for providing the facilities needed. Authors acknowledge Khattri Perfumers Pvt. Ltd. Lucknow for GC-MS analysis.

\section{CONFLICT OF INTEREST}

The Author(s) declare(s) that they have no conflicts of interest to disclose.

\section{REFERENCES}

1. Biswas K, Chattopadhyay I, Banerjee RK, Bandyopadhyay U. Biological activities and medicinal properties of neem (Azadirachta indica). Currnt Sci. 2002; 82(11):1336-45.

2. Jain SK. Medicinal Plants. National Book Trust, India. 1979.

3. Prakasha HM, Krishnappa M, Krishnamurthy YL, Poornima SV. Folk medicine of NR Pura Taluk in Chikamaglur district of Karnataka. Indian J Trad Knowl. 2010; 9(1):55-60.

4. Roche EB. Design of Biopharmaceutical Properties through Prodrugs and Analogs (American Pharmaceutical Association Academy of Pharmaceutical Sciences). (Washington, D.C.) 1977.

5. Spelman K, Duke JA, Bogenschutz, Godwin MJ. The synergy principle in plants, pathogens, insects, herbivores and humans. In: Kaufman PB, ed. Natural Products from Plants. (Boca Raton, FL: CRC Press), 2006;401-501.

6. Fessenden RJ, Fessenden JS. Organic chemistry. $6^{\text {th }}$ ed. California. (Brooks/ Cole Publishing Inc). 1967;32(11):3535-7.

7. Habbal OA, Al-Jabri AA, El-Hag AG. Antimicrobial properties of Lawsonia inermis (henna): A review. Aust J Med Herbal. 2007;19(3):114-25.

8. Habbal OA, Ai-Jabri AA, El-Hag AH, Al-Mahroog ZH, Al- Hashmi NA. In vitro antimicrobial activity of Lawsonia inermis Linn (henna) - A pilot study on the Omani henna. Saudi Medical Journal. 2005;26(1):69-72.

9. Okigbo RN, Eme UE, Ogbogu S. Biodiversity and conservation of medicinal and 
aromatic plants in Africa. Biotechnol Mol Biol Rev. 2008;3(6):127-34.

10. Gonzalez-Lamothe R, Mitchell G, Gattuso M, Moussa S, Malouin DF, Bouarab K. Plant antimicrobial agents and their effects on plant and human pathogens. Int J Mol Sci. 2009;10(8):3400-19.

11. Srivastava J, Lambert J, Vietmeyer N. Medicinal plants: An expanding role in development. (World Bank Paper No. 320) 1996.

12. Blanks T, Brown S, Cosgrave B, Woody J, Bentley VO, Sullivan N. The Body Shop Book of Wellbeing mind, body and soul. (London: Ebury Press), 1998;173-92.

13. Owolabi J, Omogbai EKI, Obasuyi, O. Antifungal and antibacterial activities of the ethanolic and aqueous extract of Kigella Africana (Bignoniaceae) stem bark. Afr J Biotechnol. 2007;6(14):882-5.

14. Kali A. Antibiotics and bioactive natural products in treatment of methicillin resistant Staphylococcus aureus: A brief review. Phcog Rev. 2015;9(17):29-34.

15. Tabassum N, Hamdani M. Plants used to treat skin diseases. Phcog Rev. 2014;8:52-60

16. Kannahi M, Vinotha K. Antimicrobial activity of Lawsonia inermis leaf extracts against some human pathogens. Int J Curr Microbiol App Sci. 2013;2(5):342-9.

17. Sastri BN. The Wealth of India Raw Materials. The Council of Scientific and Industrial Research. 1962;6(L-M):47-50.

18. Gupta AK. Quality standards of Indian medicinal plants. Indian Council of Medicinal Research. 2003;1:123-129.

19. Hemem SS. Activity of some plant extracts against common pathogens in bacterial skin infection, MSc thesis, College of Education, Basra University. Iraq. 2002

20. Muhammad HS, Muhammad S. The use of Lawsonia inermis Linn. (Henna) in the management of burn wound infection. African Journal of Biotechnology. 2005;4(9):934-7.

21. Singh M, Jindal SK, Kavia ZD, Jangid BL, Khem C. Traditional Methods of Cultivation and Processing of Henna. Henna, Cultivation, Improvement and Trade: 21-14, Jodhpur, India: Central Arid Zone Research Institute. 2005.

22. Jiny VK, Silvipriya KS, Resmi S, Jolly Cl. Lawsonia inermis (henna): a natural Dye of various therapeutic uses - a review. Inventi Impact: Cosmeceuticals. 2010;3:10.

23. Charoensup R, Duangyod T, Palanuvej C, Ruangrungsi N. Pharmacognostic specifications and lawsone content of Lawsonia inermis leaves. Phcog Res. 2017:9(1):60-4

24. Benaissa K, Belhamra M. An optimization of the extraction and the physicochemical proprieties of the essential oil of Lawsonia inermis L. cultivated in Biskra (Department of Algeria). Indian Journal of Pharmaceutical Education and Research. 2017;51(3):286-9.

25. Nohynek GJ, Fautz R, Benech-Kieffer F, Toutain H. Toxicity and human health risk of hair dyes. Food Chem Toxicol. 2004;42(4):517-43.

26. Chaudhary G, Goyal S, Poonia P. Lawsonia inermis Linnaeus: A Phytopharmacological Review. International Journal of Pharmaceutical Sciences and Drug Research. 2010;2(2):91-8

27. Ali BH, Bashir AK, Tanira MO. Anti-inflammatory, antipyretic, and analgesic effects of Lawsonia inermis L. (henna) in rats. Pharmacology. 1995:51(6):356-63.

28. Kelmanson JE, Jager AK, Staden JV. Zulu medicinal plants with antibacterial activity. J Ethnopharm. 2000;69(3):241-6

29. Singh A, Singh DK. Molluscicidal activity of Lawsonia inermis and its binary and tertiary combinations with other plant derived molluscicides. Indian J Exp Biol. 2001;39:263-8

30. Arun P, Purushotham KG, Johnsy J, Vasantha K, Chamundeeswari D. Screening Antibacterial Activity of Various Extracts of Lawsonia inermis. Res J Pharmacogn Phytochem. 2010;2(3):103-8.

31. Sharma A, Sharma K. Assay of Antifungal Activity of Lawsonia inermis Linn and Eucalyptus citriodora. Hook. J Pharm Res. 2011;4(5):1313-4.

32. Al-Rubiay KK, Jaber NN, Al-Mhaawe BH, Alrubaiy LK. Antimicrobial efficiency of Henna extract. Oman Med J. 2008;200(23):253-6.

33. Papageorgiou VP, Assimopoulou AN, Couladouros EA, Hepworth D, Nicolaou $\mathrm{KC}$. The chemistry and biology of alkannin, shikonin, and related naphthazarin natural products. Angew Chem. 1999;38(3):270-300.

34. Gull I, Maria S, Muhammad SA, Muhammad AA. Phytochemical, toxicological and antimicrobial evaluation of Lawsonia inermis extracts against clinical isolates of pathogenic bacteria. Annals of Clinical Microbiology and Antimicrobials. 2013;12(1):36.

35. Muhit MA, Tareq SM, Apu AS, Basak D, Islam MS. Isolation and Identification of Compounds from the Leaf Extract of Dillenia indica Linn. Bangladesh Pharmaceutical Journal. 2010;13(1):49-53.

36. Debela A. Manual for Phytochemical Screening of Medicinal Plants. Ethiopian Health and Nutrition Research Institute, Addis Ababa, Ethiopia. 2002;35-47.

37. Mukhtar MD, Tukur A. Antibacterial activities of aqueous and ethanolic extracts of P. stratiotes. J Nig Soc Of Exp Biol. 2000;1(1):51-9

38. Parekh J, Nair R, Chanda, S. Preliminary screening of some folklore medicinal plants from western India for potential antimicrobial activity. India J Pharmacol 2005;37:408-9.

39. Rajeswari J, Rani. SGC-MS Analysis of Phytochemical Compounds in the
Ethanolic Extract of Root of Lawsonia inermis Linn. Int J Chem Tech Res. $2015 ; 7(1): 389-99$

40. Fa-Rong Y, Xiu-Zhen L, Hong-Yun G, Peter MM, Ren-De L, Rui W, et al. Isolation and characterization of methyl esters and derivatives from Euphorbia kansui (Euphorbiaceae) and their inhibitory effects on the human SGC-7901 cells. J Pharm Pharmaceut Sci. 2005;8(3):528-35

41. Mehta SK, Jayprakash B, Nayeem N. Isolation and photochemical investigation on leaves of Buchanania Lanzan (Chironji). Annals of Biological Research. 2011 2(3):469-473.

42. Shettima AY, Karumi Y, Sodipo OA, Usman H, Tijjani MA. Gas ChromatographyMass Spectrometry (GC-MS) Analysis of Bioactive Components of Ethyl Acetate Root Extract of Guiera senegalensis J.F. Gmel Journal of Applied Pharmaceutical Science. 2013;3(3):146-150.

43. Dr. Duke's Phytochemical and Ethnobotanical Databases.

44. Gnanavel V, Saral MA. GC-MS analysis of petroleum ether and ethanol leaf extracts from Abrus precatorius Linn. International journal of Pharma and Bio science. 2013;4(3):37-44.

45. Yassa N, Masoomi F, Rohani Rankouhi SE, Hadjiakhoondi A. Chemical composition and antioxidant activity of the extract and essential oil of Rosa damascene from Iran, Population of Guilan. Daru J Pharm Sci. 2009;17(3):175-80.

46. Madhuvanthi C, Kumar KS, Ceasar SA, Valivittan K, Srinivasan K, Tamilselv A. Antibacterial, antioxidant and antiproliferative activities of solvent extracts of Tiliacora acuminate. International Journal of Pharmacy and Pharmaceutical Sciences. 2014;6(9):398-403.

47. Sivasubramanian R, Brindha P. In vitro cytotoxic, antioxidant and GC-MS studies on centratherum punctatum cass. Int J Pharm Pharm Sci. 2013;5(3):364-7.

48. Squalene-based adjuvants in vaccines, Global Advisory Committee on Vaccine Safety, World Health Organization.

49. Maret GT, Jeffrey A. Vitamin E, Antioxidant and nothing more. Free Radic Biol Med. 2007;43(1):4-15

50. Hirose N, Kuriyama S, Toyoshima S. Anti-inflammatory activity of some 2, 3 dihydrobenzofuran-5-acetic acids and related compounds. J Med Chem 1976;19(2):303-8.

51. Kathuria V, Pathak DP. Synthesis and Anticonvulsant Activity Of Some N-Substituted-Phthalimide Analogs. The Pharma Innovation. 2012;1(10):55-9.

52. Jeyachandran M, Ramesh P. Synthesis, Antimicrobial, and Anticoagulant Activities of 2-(Arylsulfonyl) indane-1, 3-diones. Organic Chemistry Internationa. 2011;1-5.

53. Mehnaz K, Ashok KS, Talha J. Benzofurans: a new profile of biological activities International Journal of Medical and Pharmaceutical Sciences. 2011;1(3):1-15.

54. Babula P, Adam V, Havel L, Kizek R. Naphthoquinones and their Pharmacological Properties. Ceska a Slovenska Farmacie. 2007;56(3):114-20.

55. Biswal S, Sahoo U, Sethy S, Kumar HK, Banerjee M. Indole: the molecule of diverse biological activities. Asian J Pharm Clin Res. 2012;5(1):1-6.

56. Rokade YB, Sayyed ZR. Naphthalene derivatives: A new range of Antimicrobials with high therapeutic value. Rasayan J Chem. 2009;2(4):972-80.

57. Sermakkani M, Thangapandian V. GC-MS Analysis of Cassia italica Leaf Methanol Extract. Asian Journal of Pharmaceutical and Clinical Research. 2012;5(2):90-4.

58. Naga VKA, Venkata RB, Kasetti RB, Chippada A. Antoxdant activity and GC-MS analysis of Phragmytes vallatoria leaf ethanolic extract. Int Res J Pharm. 2012; 3(3):252-4.

59. Asli U, Atilla Ö, Elif L. Antimicrobial and antifungal activity study of poly substituted benzene derivatives. Commun Fac Sci Univ Ank Series. 2009;55(1):17-22.

60. Ramalakshmi S, Muthuchelian K. Analysis of Bioactive constituents from the Ethanolic leaf extract of Tabebuia rosea (Bertol.) DC by Gas chromatographyMass Spectrometry. Int J Chem Tech Res. 2011;3(3):792-8.

61. Kawo AH, Kwa AM. Phytochemical screening and antibacterial activity of the aqueous extracts and fractions of ethanolic extracts of Lawsonia inermis leaf. International Research Journal of Microbiology. 2011;2(12):510-6.

62. Panchaksharam S, Kuravappullam VR. Estimation of Phenolic Compounds Present in the Plant Extracts Using High Pressure Liquid Chromatography, Antioxidant Properties and its Antibacterial Activity. Indian Journal of Pharmaceutical Education and Research. 2018;52(2): 321-6.

63. Maurya R, Akansha J. Chemistry and pharmacology of Withania coagulans: An Ayurvedic remedy. J Pharma Pharmacol. 2010;62(2):153-60.

64. Dama LB, Poul BN, Jadhav BV. Antimicrobial activity of Napthoquinonic compounds. J Ecotoxicology and Environmental Monitoring. 1998;8(3):213-5.

65. Kim MG, Jeon JH, Lee HS. Larvicidal activity of the active constituent isolated from Tabebuia avellanedae bark and structurally related derivatives against three mosquito species. J Agric Food Chem. 2013;61(45):10741-5.

66. Sarojini N, Kanti CC, Manjari SA, Usha Kumari S, Priyanka J. In vitro antibacterial activities of Lawsonia inermis leaf extracts. International Research Journal of Pharmacy. 2012;3(7):195-7. 
GRAPHICAL ABSTRACT

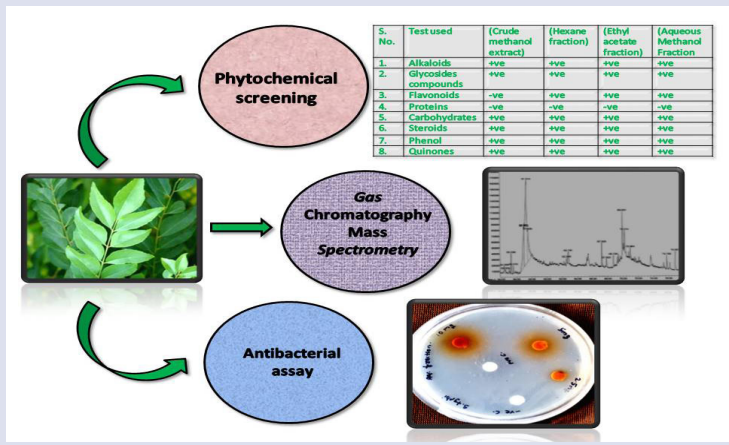

ABOUT AUTHORS

\section{SUMMARY}

- Lawsonia inermis is a well-known ethno medicinal plant used cosmetically and medicinally for over 9,000 years. Its use in the Indian traditional folk medicines is well documented. It belongs to the Lythraceae family (a family of flowering plants that includes 620 species). It is the only plant species in the genus Lawsonia.

- Phytochemical screening of extract confirmed the presence of carbohydrates, glycosides, quinones, steroids and phenol. In GC-MS chromatograms, 56, 108 and 19 peaks were obtained and out of these, 13,17 and 7 compounds were identified in hexane, ethyl acetate and aqueous methanol fractions, respectively.

- For best of our knowledge in $L$ inermis leaves extract, Celidoniol and Vitamin $\mathrm{E}$ has not been reported earlier in hexane fractions. While 2, 3 dihydrobenzo furan, 1-H indole -1, 3 (2H)-dione, 1 (3H)-Isobenzofuranone, 1H Isoindole-1, 3 (2H) Dione, Napthelene, 2 ethoxy, 2 (4H) Benzofuranone, Vitamin E, Benzene, 1 isocyano 4 methyl are also identified for the first time in ethyl acetate fraction. Also, in aq. Methanol fraction $1(3 \mathrm{H})$ isobenzofuranone, Squalene and Vit E were not previously identified. Highest antibacterial activity was confirmed in crude methanol extract which might be due to all the antibacterial compounds present in its fractions. The present study helped in identifying phytoconstituents present in the extract and its fractions which are responsible for various biological and antibacterial activities.
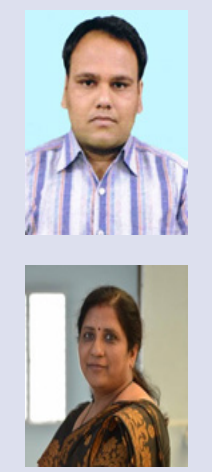

Ritesh Kumar Sharma, a Doctoral Candidate at Department of Biotechnology, Institute of Applied Sciences and Humanities, GLA University, Mathura, India. The doctoral research is focused on the induction of cytokine by $L$. inermis Linn. and its role in protection against bacterial infections.

Dr. Anjana Goel is currently working as Associate Professor, Dept of Biotechnology, GLA University, Mathura. She has done her Ph.D. from Central Drug Research Institute, Lucknow. She has published more than 35 papers in peer-reviewed indexed national and international journals. She has presented more than 55 conference papers in India as well as abroad in National \& International Conferences. Her research interest is on medicinal plants and immunology.

Cite this article: Sharma RK, Goel A. Identification of Phytoconstituents in Lawsonia inermis Linn. Leaves Extract by GC-MS and their Antibacterial Potential. Pharmacog J. 2018;10(6):1101-8. 